\title{
Selection and genetic gains for juvenile traits in progenies of Hevea in São Paulo State, Brazil
}

\author{
Paulo de Souza Gonçalves ${ }^{1}$, Antonio Lúcio Mello Martins ${ }^{2}$, Nelson Bortoletto ${ }^{3}$ and Luis Alberto Saes ${ }^{4}$ \\ ${ }^{1}$ APTA Instituto Agronômico, Programa Seringueira, Campinas, SP, Brazil. \\ ${ }^{2}$ APTA Regional Centro Norte, Pindorama, SP, Brazil. \\ ${ }^{3}$ APTA Regional Noroeste Paulista, Votuporanga, SP, Brazil. \\ ${ }^{4}$ APTA Regional Vale do Ribeira, Pariquera-Açú, SP, Brazil.
}

\begin{abstract}
Five yield traits were investigated in three-year-old progenies from open-pollinated rubber trees [Hevea brasiliensis (Willd. ex Adr. de Juss) Muell.-Arg.]. Twenty progenies were evaluated in a randomized, complete block design replicated three times using 10 plants per linear plot at the North Central Experimental Station in Pindorama, São Paulo State, Brazil. The characters evaluated included the average yield of rubber, growth vigor, bark thickness, total number of latex vessel rings and latex vessel size. Highly significant $(p<0.01)$ genetic differences were observed among progenies for most traits. The genotypic variance components accounted for $13.2 \%, 12.3 \%, 9.4 \%, 3.4 \%$ and $0.23 \%$ of the phenotypic variance for yield, growth vigor, bark thickness, total number of latex vessel rings and latex vessel size, respectively. Heritabilities, as well as genotypic and phenotypic correlations among traits, were estimated. Heritabilities for the above traits at the individual plant level $\left(h_{i}^{2}\right)$ were $37 \%, 35 \%, 69 \%, 10 \%$ and $16 \%$, respectively. Significant positive genotypic and phenotypic correlations were found between the yield of rubber and growth vigor $\left(r_{g}=0.73, r_{p}=0.70\right)$, bark thickness $\left(r_{g}=0.70^{\star \star}, r_{p}=0.75^{\star \star}\right)$ and the total number of latex vessel rings $\left(r_{g}=0.64, r_{p}=0.80\right)$. There was no relationship between yield and latex vessel size, growth vigor or total number of latex vessel rings. Based on these data, selecting the best two out of 20 progenies would result in a genetic gain of $12.3 \%$ and $6.8 \%$ for yield of rubber and growth vigor, respectively. The two best individual ortets within each progeny would result in a genetic gain of $27.7 \%$ and $9.1 \%$, with a total gain of $40 \%$ and $16 \%$ for these two traits, respectively.
\end{abstract}

Key words: Hevea brasiliensis, rubber tree, heritability, genetic parameters.

Received: October 16, 2002; Accepted: November 14, 2003.

\section{Introduction}

The success of a rubber tree [Hevea brasiliensis (Willd. ex Adr. de Juss) Muell.-Arg.] breeding program depends, to a large extent, on knowledge of the genetic aspects involved and on the recognition of traits considered important for plant selection. Information on the genetic variability or heritability of traits that are to be improved is extremely important and of vital importance for prediction of the final outcome.

The rubber tree is a tree crop with a long generative and testing cycle. A single generative cycle requires 4-5 years (excluding 7-10 years for the evaluation of parental performance) and about 20-30 years for one testing cycle from the time of pollination. Thus, one of the most desirable innovations in tree breeding is a technique for predict-

Send correspondence to Paulo de Souza Gonçalves. Instituto Agronômico de Campinas (IAC), Programa Seringueira, Caixa Postal 28, Av. Barão de Itapura 1481, 13001-970 São Paulo, SP, Brazil. E-mail: paulog@iac.sp.gov.br. ing the breeding value of the trees at the juvenile stage (Varghese, 1999).

Studies on genetic variation have been done in Malaysia (Nga and Subramanian, 1974; Tan et al., 1975; Tan and Subramanian, 1976; Tan, 1977, 1978a,b) and Nigeria (Alika and Onokpise, 1982; Alika, 1985). In Brazil, studies on the genetic variation of various traits have been done by Siqueira (1978), Valois et al. (1978), Paiva et al. (1982, 1983), Gonçalves et al. (1990, 1992, 1996), Moreti et al. (1994), Boock et al. (1995) and Costa (1999).

The aim of this work was to estimate the genetic variability, heritability coefficients, and the relative genetic gains for the yield traits of rubber tree progenies in order to obtain information necessary for choosing the most appropriate methods of breeding selection.

\section{Materials and Methods}

The material for this experiment consisted of seeds from 20 open-pollinated progenies randomly selected from 
a population base of 100 Asiatic clones. The seeds were sown in the autumn of 1998 in individual polyethylene bags $(12 \mathrm{~cm} \times 18 \mathrm{~cm} \times 18 \mathrm{~cm})$ filled with a mixture of $70 \% \mathrm{hu}-$ mus and $30 \%$ sand. The seedlings remained in these pots during the first six months of the growing season and were subsequently planted out at the Pindorama Experimental Station (21 ${ }^{\circ} 13^{\prime}$ S, $\left.48^{\circ} 56^{\prime} \mathrm{W}\right)$. The space between rows and between trees within rows was $1.5 \mathrm{~m}$. This region has a humid, tropical climate with a mean yearly temperature of $21{ }^{\circ} \mathrm{C}$ and a red yellow podzolic type soil (Lepsch and Valadares, 1976).

The experiments were done using a randomized block design with three replications and 10 plants per plot. A clone trial consisting of a randomized block design with 25 clones, three replications and six plants per plot along with the progenies trial. The dates and procedures were similar to those of the progenies trial. The clone trial was designed to provide an estimate of the environmental variance among plants within plots $\left(\hat{\sigma}_{e w}^{2}\right)$ (Vencosvsky and Barriga, 1992).

\section{Measurements}

The yield of rubber was determined using the principle of the Hamker-Morris-Mann test (HMM) (Tan and Subramanian, 1976), as follows: 30 tappings were made with a half-spiral, alternative daily $(1 / 2 \mathrm{~S} \mathrm{~d} / 3)$ tapping system $20 \mathrm{~cm}$ from the ground. The yield was recorded by cup coagulation. The "coagula" were air-dried for two months until a constant weight was achieved. The yield from each plant was expressed in grams per tapping.

Growth vigor was determined as the girth of the seedling measured once a year. The first measurement at 12 months was of the diameter because the plants were too small to measure growth vigor. Plant diameter was measured $0.50 \mathrm{~m}$ from the ground level with a slide clipper. This measurement was converted to growth vigor by assuming that the stem was cylindrical. Another measurement was taken at 24 months at $50 \mathrm{~cm}$ above the ground using a measuring tape.

For latex vessel counts, virgin bark samples were removed from the trunk as plugs $20 \mathrm{~cm}$ from the ground on the opposite side of the tapping panel. Bark thickness was measured using samples from each seedling.
The total number of latex vessel rings was determined by examining the radial longitudinal sections of the same bark samples. Latex vessel size was expressed as the diameter of latex vessels observed in transverse sections of the same bark samples. Complete details of the procedure are described by Gonçalves et al. (1995).

\section{Analysis of variance (ANOVA)}

The analysis using the statistical model below considered all variables (except mean) as random effects.

$$
y_{i j k}=\mu+p_{i}+b_{j}+e_{i j}+d_{i j k}
$$

where $y_{i j k}=$ observed value of the $k$ th plant in the $j$ th replication within the $i$ th progeny, $\mu=$ general mean, $p_{i}=$ effect of the $i$ th progeny $(p=1,2, \ldots 20), b_{j}=$ effect of the $j$ th replication $(j=1,2,3), e_{i j}=$ experimental error associated with the $i j$ th plot and $d_{i j k}=$ effect of the $k$ th plant within the $i j$ th plot.

Estimates of the components of genotypic and phenotypic variances were obtained by the mathematical expected mean squares from the analyses of variance (Table 1), according to Vencovsky and Barriga (1992). Thus, the phenotypic variance due to differences among plants within plots was:

$$
\hat{\sigma}_{w}^{2}=M S W
$$

where $\hat{\sigma}_{w}^{2}=\hat{\sigma}_{g w}^{2}+\hat{\sigma}_{e w}^{2}$, which can be separated into genetic $\left(\hat{\sigma}_{g w}^{2}\right)$ and environmental $\left(\hat{\sigma}_{e w}^{2}\right)$ variances among plants within plots.

Partitioning the component $\hat{\sigma}_{w}^{2}$ into $\hat{\sigma}_{g w}^{2}$ and $\hat{\sigma}_{e w}^{2}$ suggested that it would be possible to use information from the mean square within plots of the clones trial (Table 2) to provide estimates of the environmental variance within plots $\left(\hat{\sigma}_{e w}^{2}\right)$. Thus, the environmental and genetic variances among plants within plots were obtained by the mean squares (Tables 3 and 4).

$$
\begin{aligned}
& \hat{\sigma}_{e w}^{2}=M S W C \\
& \hat{\sigma}_{g w}^{2}=M S W-M S W C
\end{aligned}
$$

Estimates of the environmental variance among plots $\left(\hat{\sigma}_{e}^{2}\right)$ and of genotypic variance due to differences among

Table 1 - Degrees of freedom (df), mean square (MS) and expected mean square (EMS) for estimating the variance due to differences among plants within plots in a clonal trial of rubber trees.

\begin{tabular}{lcccc}
\hline Sources of variation & $\mathrm{df}$ & MS & EMS & F test \\
\hline Replications & $\mathrm{r}-1$ & MSR & - & MSR/MSE \\
Progenies & $\mathrm{p}-1$ & $\mathrm{MSP}$ & $\hat{\sigma}_{w / \bar{n}}^{2}+\hat{\sigma}_{e}^{2}+r \hat{\sigma}_{j}^{2}$ & MSP/MSE \\
Progenies x replications & $(\mathrm{r}-1)(\mathrm{p}-1)$ & $\mathrm{MSE}$ & $\hat{\sigma}_{w / \bar{n}}^{2}+\hat{\sigma}_{e g}^{2}$ & MSE/MSW \\
Within progenies & $\mathrm{rp} \mathrm{(n-1)}$ & $\mathrm{MSW}$ & $\hat{\sigma}_{w}^{2}$ & \\
Total & $\mathrm{rpn}-1$ & & & \\
\hline
\end{tabular}

$\hat{\sigma}_{w}^{2}=$ variance due to differences among plants within plots, $\hat{\sigma}_{e}^{2}=$ environmental variance among plots, $\sigma_{e g}=$ genotypic variance due to differences among progenies, $\mathrm{r}=$ number of replications, $\mathrm{f}=$ number of progenies, $\bar{n}=$ number of plants per plot (harmonic mean). 
Table 2 - Degrees of freedom (df), mean square (MS) and expected mean square (EMS) for estimating the variance due to differences among plants within plots in a clone trial of rubber trees.

\begin{tabular}{lcccc}
\hline Sources of variation & df & MS & EMS & F test \\
\hline Replications & $\mathrm{r}-1$ & MSRC & - & MSRC/MSEC \\
Clones & $\mathrm{c}-1$ & MSC & - & MSC/MSEC \\
Clones x replications & $(\mathrm{r}-1)(\mathrm{c}-1)$ & MSEC & - & MSEC/MSWC \\
Within clones & rc (n-1) & MSWC & $\sigma_{e w}{ }^{2}$ & \\
Total & rcn-1 & & & \\
\hline
\end{tabular}

$\sigma_{e w}{ }^{2}=$ variance due to differences among plants within plots, $\mathrm{r}=$ number of replications, $\mathrm{c}=$ number of clones, $\mathrm{n}=$ number of plants per plot.

progenies $\left(\hat{\sigma}_{g}^{2}\right)$ were obtained through the expected mean square, as shown in Table 1.

The total genotypic variance $\left(\hat{\sigma}_{G}^{2}\right)$, phenotypic variance based on progeny means $\left(\hat{\sigma}_{\overline{\hat{V}}}^{2}\right)$, and phenotypic variance based on individual plants $\left(\hat{\sigma}_{p}^{2}\right)$ were obtained using the expressions:

$$
\begin{aligned}
& \hat{\sigma}_{G}^{2}=\hat{\sigma}_{g}^{2}+\hat{\sigma}_{g w}^{2} \\
& \hat{\sigma}_{\bar{p}}^{2}=\hat{\sigma}_{g}^{2}+\frac{\hat{\sigma}_{e}^{2}}{r}+\frac{\hat{\sigma}_{w}^{2}}{r n} \\
& \hat{\sigma}_{p}^{2}=\hat{\sigma}_{g}^{2}+\hat{\sigma}_{e}^{2}+\hat{\sigma}_{w}^{2}
\end{aligned}
$$

\section{Heritabilities and gain estimates}

The heritability coefficients at the individual plant level $\left(\hat{h}_{i}^{2}\right)$, for selection within progeny $\left(\hat{h}_{w}^{2}\right)$, and for the among progenies mean $\left(\hat{h}_{g}^{2}\right)$, were estimated using the expressions (Vencovsky and Barriga, 1992):

$$
\begin{aligned}
& \hat{h}_{i}^{2}=\hat{\sigma}_{G}^{2} / \hat{\sigma}_{P}^{2} \\
& \hat{h}_{w}^{2}=\hat{\sigma}_{g w}^{2} / \hat{\sigma}_{w}^{2} \\
& \hat{h}_{g}^{2}=\hat{\sigma}_{g}^{2} / \hat{\sigma}_{\bar{P}}^{2}
\end{aligned}
$$

Table 3 - Degrees of freedom (df) and mean squares from ANOVA, general mean, and experimental $\left(\mathrm{CV}_{e} \%\right)$ and genotypic $\left(\mathrm{CV}_{g} \%\right)$ coefficients of variation for five traits in 20 open pollinated rubber tree progenies.

\begin{tabular}{lcccccc}
\hline Source of variation & df & $\begin{array}{c}\text { Yield of rubber } \\
(\mathrm{g} / \mathrm{t} / \mathrm{t})^{1}\end{array}$ & $\begin{array}{c}\text { Growth vigor }{ }^{2} \\
(\mathrm{~cm})\end{array}$ & $\begin{array}{c}\text { Bark thickness } \\
(\mathrm{mm})\end{array}$ & $\begin{array}{c}\text { Total number of } \\
\text { latex vessel rings }\end{array}$ & $\begin{array}{c}\text { Latex vessel size } \\
(\mu \mathrm{m})\end{array}$ \\
\hline Replications & 3 & 0.1795 & 7.6527 & 0.0533 & 0.0059 & 0.8023 \\
Progenies & 19 & $1.6984^{* *}$ & $43.9567^{* *}$ & $0.5247^{* *}$ & 0.0270 n.s. & $2.1306^{*}$ \\
Progenies x replications & 57 & 0.6140 n.s. & 12.2838 n.s. & 0.1165 n.s. & 0.0223 n.s. & 1.2261 n.s. \\
Within plots & 400 & 2.4040 & 53.1168 & 0.6639 & 0.1016 & 6.2422 \\
General mean & & 2.37 & 27.63 & 3.68 & 3.61 & 33.73 \\
$\mathrm{CV}_{e} \%$ & & 33.13 & 12.68 & 9.98 & 4.13 & 3.25 \\
$\mathrm{CV}_{g} \%$ & 22.01 & 10.18 & 8.69 & 0.96 & 1.41 \\
\hline
\end{tabular}

${ }^{*} \mathrm{p}<0.05,{ }^{* *} \mathrm{p}<0.01, \mathrm{n} . \mathrm{s} .=$ not significant. ${ }^{1} \mathrm{~g} / \mathrm{t} / \mathrm{t}-$ grams per tree per tapping.

${ }^{2}$ Expressed as the girth of the progenies measured $20 \mathrm{~cm}$ from the ground.

Table 4 - Degrees of freedom (df) and mean squares from ANOVA, general mean, and experimental $\left(\mathrm{CV}_{g} \%\right)$ and genotypic $\left(\mathrm{CV}_{g} \%\right)$ coefficients of variation for five traits in 25 rubber tree clones.

\begin{tabular}{lcccccc}
\hline Sources of variation & df & $\begin{array}{c}\text { Yield of rubber } \\
(\mathrm{g} / \mathrm{t} / \mathrm{t})^{1}\end{array}$ & $\begin{array}{c}\text { Growth vigor } \\
(\mathrm{cm})\end{array}$ & $\begin{array}{c}\text { Bark thickness } \\
(\mathrm{mm})\end{array}$ & $\begin{array}{c}\text { Total number of } \\
\text { latex vessel rings }\end{array}$ & $\begin{array}{c}\text { Latex vessel size } \\
(\mu \mathrm{m})\end{array}$ \\
\hline Replications & 2 & 6.5860 & 6.0771 & 0.1078 & 0.0466 & 0.1231 \\
Clones & 24 & $4.0961^{* *}$ & $1.8780^{* *}$ & $0.1160^{* *}$ & $0.0243^{* *}$ & $0.2556 \mathrm{n}$. s. \\
Clones x replications & 48 & 0.2344 n.s. & $0.3096^{* *}$ & 0.0246 n.s. & 0.0067 n.s. & 0.4817 n.s. \\
Within clones & 900 & 1.6030 & 0.0449 & 0.2240 & 0.0148 & 5.4080 \\
General mean & & 3.30 & 25.00 & 2.80 & 4.20 & 25.00 \\
$\mathrm{CV}_{e} \%$ & & 23.88 & 11.21 & 9.30 & 6.10 & 16.92 \\
$\mathrm{CV}_{g} \%$ & 15.77 & 11.25 & 11.41 & 0.70 & 1.90 \\
\hline
\end{tabular}

${ }^{*} \mathrm{p}<0.05,{ }^{* *} \mathrm{p}<0.01, \mathrm{n} . \mathrm{s} .=$ not significant. ${ }^{1} \mathrm{~g} / \mathrm{t} / \mathrm{t}-$ grams/tree/tapping

${ }^{2}$ Expressed as the girth of the progenies measured $20 \mathrm{~cm}$ from the ground. 
The coefficients of genotypic variation $\left(\mathrm{CV}_{\mathrm{g}} \%\right)$ were estimated using the formula described by Vencovsky (1983):

$$
C \hat{\mathrm{V}}_{\mathrm{g}} \%=\frac{\sqrt{\hat{\sigma}_{g}^{2}}}{\bar{x}} .100
$$

Genetic gain from selection among progenies $\left(G_{g}\right)$ and within progenies $\left(G_{w}\right)$ was also computed using Falconer and Mackay's (1996) formula:

$$
\begin{aligned}
& G_{g}=k_{1} \hat{\sigma}_{\bar{P}} \hat{h}_{g}^{2} \\
& G_{w}=k_{2} \hat{\sigma}_{w} \hat{h}_{w}^{2}
\end{aligned}
$$

where $k=$ the selection differential in a standard measure, $\hat{\sigma}_{\bar{P}}=$ the phenotypic standard deviation of the progeny means, and $\hat{\sigma}_{w}=$ the phenotypic standard deviation among plants within plots.

The genetic gain expressed as a percent of the mean obtained from among and within progenies was estimated using the formula:

$$
G_{g} \%=\frac{G_{g}}{\bar{x}} \cdot 100 \text { or } G_{w} \%=\frac{G_{w}}{\bar{x}} \cdot 100
$$

where $\bar{x}$ is the general mean.

\section{Correlations coefficients}

To examine the relationship among the yield traits of rubber trees, genotypic $\left(r_{g(x y)}\right)$ and phenotypic $\left(r_{p(x y)}\right)$ correlation coefficients were calculated according to Kempthone (1966), as follows:

$$
\begin{aligned}
& r_{g(x y)}=\frac{\operatorname{Cov}_{g(x y)}}{\sqrt{\sigma_{g x}^{2} \cdot \sigma_{g y}^{2}}} \\
& r_{p(x y)}=\frac{\operatorname{Cov}_{p(x y)}}{\sqrt{\sigma_{p x}^{2} \cdot \sigma_{p y}^{2}}}
\end{aligned}
$$

where $\operatorname{Cov}_{g(x y)}$ and $\operatorname{Cov}_{p(x y)}=$ the genotypic and phenotypic covariances for traits $x$ and $y$ respectively, $\sigma_{g x}{ }^{2}$ and $\sigma_{p x}{ }^{2}=$ genotypic and phenotypic variances for trait $x$, and $\sigma_{g y}{ }^{2}$ and $\sigma_{p y}{ }^{2}=$ genotypic and phenotypic variances for trait $y$.

The significance of these correlations was tested using the table in Fisher and Yates (1971) for simple correlations for $5 \%$ and $1 \%$ probabilities. The genotypic and phenotypic correlation coefficients were tested using the degrees of freedom of the error.

\section{Results and Discussion}

\section{Genotypic variation}

Except for the total number of latex vessel rings, highly significant among-progeny differences were de- tected by the F test (Table 3 ). This variability is an essential condition for establishing a genetic breeding program and could be effectively exploited to increase rubber tree production.

The experimental coefficients of variation $\left(\mathrm{CV}_{e} \%\right)$ obtained for yield of rubber (33.1\%), growth vigor (12.7\%) and bark thickness $(10 \%)$ indicated that these traits were subject to considerable experimental error. However, these values agreed with similar estimates by Gonçalves et al. (1998), Moreti et al. (1994), Boock et al. (1995) and Costa et al. (2000a).

The genotypic variation coefficient, which expresses the amount of existing genetic variation as a percentage of the general mean, was higher for the yield of rubber $(22 \%)$ than for growth vigor (10.2\%), bark thickness (8.7\%), latex vessel size (1.4\%) and total number of vessel rings (0.96\%). These results confirmed the $\mathrm{F}$ test results for progeny differences and characterized the yield of rubber as a more suitable trait expressing the genetic variability in this population. These results also agreed with those reported by Gonçalves et al. (1998) and Boock et al. (1995) for the same traits.

Table 4 shows the clone trial analysis of variance. Except for latex vessel size, significant among-clone differences were detected by the F test for all traits. These results reinforce the variability observed in the progeny trial, an essential condition for establishing a genetic breeding program. The main purpose of the clone analysis of variance was to supply an estimate of the environmental variance among plants within plots.

\section{Progeny variance components}

The genotypic variance components among progenies accounted for $13.2 \%, 12.2 \%, 9.4 \%, 3.4 \%$ and $0.83 \%$ of the phenotypic variance based on individual plants for bark thickness, growth vigor, yield of rubber, latex vessel size and latex vessel rings, respectively (Table 5). The contribution of genotypic variance among progenies accounted for $\hat{\sigma}_{2}^{g}=13.7 \%$ for bark thickness of the total genotypic variance and was substantially smaller than that for growth vigor $\left(\hat{\sigma}_{2}^{g}=35.4 \%\right)$. In addition, the estimates of the growth vigor were substantially greater than for the other traits.

\section{Heritabilities}

The mean heritability among progenies for the yield of rubber and growth vigor at the individual plant level $\left(h_{i}^{2}\right)$ were relatively low, with values of 0.37 and 0.34 , respectively (Table 6). These data agreed with the results of Costa et al. (2000a,b), Gonçalves et al. (1998, 1999), Boock et al. (1995) and Moreti et al. (1994). Gonçalves et al. (1998, 1999) reported individual plant heritabilities of $h_{i}^{2}=0.37$ and $h_{i}{ }^{2}=0.51$ for the yield of rubber, whereas Costa et al. (2000a) and Boock et al. (1995) reported values of $h_{i}^{2}=0.24$ and $h_{i}^{2}=0.35$, respectively, at Votuporanga. In 
Table 5 - Estimates of genotypic and phenotypic components of variance for five traits in 20 open-pollinated rubber tree progenies.

\begin{tabular}{|c|c|c|c|c|c|c|c|c|}
\hline \multirow[t]{2}{*}{ Traits } & \multicolumn{8}{|c|}{ Components of variance ${ }^{1}$} \\
\hline & $\hat{\boldsymbol{\sigma}}_{g}^{2}$ & $\hat{\sigma}_{e}^{2}$ & $\hat{\sigma}_{w}^{2}$ & $\hat{\sigma}_{g w}^{2}$ & $\hat{\sigma}_{e w}^{2}$ & $\hat{\sigma}_{G}^{2}$ & $\hat{\sigma}_{\bar{p}}^{2}$ & $\hat{\sigma}_{p}^{2}$ \\
\hline Rubber yield & 0.2712 & 0.2133 & 2.4040 & 0.8010 & 1.6030 & 1.0721 & 0.4246 & 2.8884 \\
\hline Growth vigor $^{2}$ & 7.9182 & 3.4312 & 53.1168 & 14.4746 & 0.0449 & 22.3928 & 10.9892 & 64.4662 \\
\hline Bark thickness & 0.1021 & 0.0058 & 0.6639 & 0.4339 & 0.2240 & 0.5361 & 0.1312 & 0.7718 \\
\hline $\begin{array}{l}\text { Total number of } \\
\text { latex vessel rings }\end{array}$ & 0.0009 & 0.0064 & 0.1016 & 0.0105 & 0.0913 & 0.0112 & 0.0067 & 0.1089 \\
\hline Latex vessel size & 0.2276 & 0.1797 & 6.2422 & 0.8342 & 5.4080 & 1.0618 & 0.5326 & 6.6495 \\
\hline
\end{tabular}

${ }^{1} \hat{\sigma}_{g}^{2}=$ genotypic variance due to differences among progenies, $\hat{\sigma}_{e}^{2}=$ environmental variance among plots, $\hat{\sigma}_{w}^{2}=$ phenotypic variance due to differences among plants within plots, $\hat{\sigma}_{g w}^{2}=$ genetic variance among plants within plots, $\hat{\sigma}_{e w}^{2}=$ environmental variance among plants within plots, $\hat{\sigma}_{G}^{2}=$ total genotypic variance, $\hat{\sigma}_{\bar{p}}^{2}=$ phenotypic variance based on progenies means, $\hat{\sigma}_{p}^{2}=$ phenotypic variance based on individual plants.

${ }^{2}$ Expressed as the girth of the progenies measured $20 \mathrm{~cm}$ from the ground.

Table 6 - Heritability coefficients for five traits in 20 open-pollinated rubber tree progenies.

\begin{tabular}{lrrr}
\hline \multirow{2}{*}{ Traits } & \multicolumn{3}{c}{ Heritabilities $^{1}$} \\
\cline { 2 - 4 } & $h_{i}{ }^{2}$ & $h_{w}{ }^{2}$ & $h_{g}{ }^{2}$ \\
\hline Rubber yield & 0.3712 & 0.3332 & 0.6385 \\
Growth vigor $^{2}$ & 0.3473 & 0.2725 & 0.7205 \\
Bark thickness & 0.6945 & 0.6536 & 0.7782 \\
Total number of latex vessel rings & 0.1028 & 0.1013 & 0.1343 \\
Latex vessel size & 0.1597 & 0.1336 & 0.4273 \\
\hline
\end{tabular}

${ }^{1} h_{i}{ }^{2}=$ individual plants, $h_{w}{ }^{2}=$ within progenies, $h_{g}{ }^{2}=$ among progenies mean.

${ }^{2}$ Expressed as the girth of the progenies measured $20 \mathrm{~cm}$ from the ground.

addition, Costa et al. (2000b) obtained a value of $h_{i}^{2}=0.11$ at Jaú. For growth vigor, values of $h_{i}^{2}=0.48$ (Gonçalves et al., 1999) and $h_{i}^{2}=0.31$ (Moreti et al., 1994) were obtained at Pindorama and $h_{i}^{2}=0.47$ (Boock et al., 1995) at Votuporanga. These results indicate that these two traits have moderately low heritability estimates and imply that there is a need to increase the genetic variability for yield and growth vigor in the population studied here.

The mean heritability among progenies $\left(h_{g}{ }^{2}\right)$ for yield of rubber and growth vigor were $h_{g}{ }^{2}=0.63$ and $h_{g}{ }^{2}=0.72$, respectively. Costa et al. (2000a) and Boock et al. (1995) reported values of $h_{g}{ }^{2}=0.80$ and $h_{g}{ }^{2}=0.73$, respectively, for yield of rubber at Votuporanga, and Costa et al. (2000b), Gonçalves et al. (1999) and Moreti et al. (1994) reported values of $h_{g}{ }^{2}=0.90, h_{g}{ }^{2}=0.91$ and $h_{g}{ }^{2}=0.89$, respectively, at Pindorama.

Values of $h_{g}{ }^{2}=0.89$ (Costa et al., 2000a) and $h_{g}{ }^{2}=0.81$ (Gonçalves et al., 1999) were reported for growth vigor at Votuporanga and Pindorama, respectively. These highly significant heritability estimates for progeny means $\left(h_{g}{ }^{2}\right)$, together with the extensive variation seen within the rubber tree population, suggest that an effort to increase yield, growth vigor, total number of latex vessel rings and latex vessel size through progeny selection would be rewarding, as also indicated by Gonçalves et al. (1999).

The mean heritability among progenies for other traits, such as the total number of vessel rings and latex vessel size, were low, i.e., $10 \%$ and $16 \%$ at the individual plant level $\left(h_{i}{ }^{2}\right), 10 \%$ and $13 \%$ within progenies $\left(h_{w}{ }^{2}\right)$ and $13 \%$ and $42 \%$ among the progeny means $\left(h_{g}{ }^{2}\right)$, respectively.

\section{Expected genetic gains}

The expected genetic gains for the traits studied at different levels of selection intensity are shown in Table 7. If the best six progenies were selected and planted at sites similar to that used in the experimental trial, a genetic gain among progenies for yield and growth vigor of $8.3 \%$ and $4.6 \%$, respectively, could be achieved. When only the two best progenies (i.e., two out of 20 progenies) were selected for yield and growth vigor with a selection intensity of $10 \%$, the gain in production would be $29.1 \mathrm{~g}$ and $188.6 \mathrm{~mm}$, which is $12.3 \%$ and $6.8 \%$ greater than the overall progeny means. Even smaller increases than these would result in appreciable improvement if the plantings were large enough.

On the other hand, if the two best individuals were selected within progenies and then asexually multiplied and planted at the same site, the genetic gain for yield and growth vigor would be about $27.7 \%$ and $9.1 \%$, respectively. For yield, growth vigor and bark thickness, the gains would be $27.7 \%, 9.1 \%$ and $18.4 \%$, respectively. Considering combined selection among and within progenies, the total genetic gains would be $40 \%, 16 \%$ and $29.5 \%$ for yield, growth vigor and bark thickness, respectively.

\section{Correlations}

Genotypic and phenotypic correlations between yield and other characters, such as growth vigor and bark thickness, were generally significant (Table 8). Progenies with high yield and high growth vigor often showed a highly significant positive correlation with bark thickness.

The influence of bark thickness on yield and growth vigor was not immediately evident in the field. High growth 
Table 7 - Expected gains from different levels of selection and percentage of the mean, among $\left(G_{g}\right)$ and within $\left(G_{w}\right)$ progenies, and selection total $\left(G_{g+w}\right)$ for five traits in 20 open-pollinated rubber-tree progenies.

\begin{tabular}{|c|c|c|c|c|c|c|c|c|c|}
\hline \multirow[t]{2}{*}{ Traits } & \multicolumn{3}{|c|}{ Selection level ${ }^{1}$} & \multicolumn{3}{|c|}{ From selection } & \multicolumn{3}{|c|}{ In percent of the mean } \\
\hline & $N$ & $K_{1}$ & $K_{2}$ & $\mathrm{G}_{g}$ & $\mathrm{G}_{w}$ & $\mathrm{G}_{g+w^{2}}$ & $\mathrm{G}_{g}$ & $\mathrm{G}_{w}$ & $\mathrm{G}_{g+w^{2}}$ \\
\hline \multirow{5}{*}{$\begin{array}{l}\text { Rubber } \\
\text { yield }\end{array}$} & 2 & 1.638 & 1.270 & 0.2909 & 0.6561 & 0.9470 & 12.27 & 27.68 & 39.95 \\
\hline & 4 & 1.332 & 0.893 & 0.2366 & 0.4613 & 0.6979 & 9.98 & 19.46 & 29.44 \\
\hline & 6 & 1.110 & 0.595 & 0.1972 & 0.3074 & 0.5046 & 8.32 & 12.97 & 21.29 \\
\hline & 8 & 0.928 & 0.318 & 0.1648 & 0.1643 & 0.3291 & 6.95 & 6.93 & 13.88 \\
\hline & 10 & 0.767 & - & 0.1362 & - & 0.1362 & 5.75 & - & 5.75 \\
\hline \multirow{5}{*}{$\begin{array}{l}\text { Growth } \\
\text { vigor }^{3}\end{array}$} & 2 & 1.638 & 1.270 & 1.8858 & 2.5222 & 4.4080 & 6.83 & 9.13 & 15.96 \\
\hline & 4 & 1.332 & 0.893 & 1.5335 & 1.7735 & 3.3070 & 5.55 & 6.42 & 11.97 \\
\hline & 6 & 1.110 & 0.595 & 1.2779 & 1.1816 & 2.4595 & 4.63 & 4.28 & 8.91 \\
\hline & 8 & 0.928 & 0.318 & 1.0684 & 0.6316 & 1.7000 & 3.87 & 2.29 & 6.16 \\
\hline & 10 & 0.767 & - & 0.8830 & - & 0.8830 & 3.20 & - & 3.20 \\
\hline \multirow{5}{*}{$\begin{array}{l}\text { Bark } \\
\text { thickness }\end{array}$} & 2 & 1.638 & 1.270 & 0.4120 & 0.6763 & 1.0883 & 11.20 & 18.38 & 29.58 \\
\hline & 4 & 1.332 & 0.893 & 0.3351 & 0.4756 & 0.8107 & 9.11 & 12.92 & 22.03 \\
\hline & 6 & 1.110 & 0.595 & 0.2792 & 0.3169 & 0.5961 & 7.59 & 8.61 & 16.20 \\
\hline & 8 & 0.928 & 0.318 & 0.2334 & 0.1694 & 0.4028 & 6.34 & 4.60 & 10.94 \\
\hline & 10 & 0.767 & - & 0.1929 & - & 0.1929 & 5.24 & - & 5.24 \\
\hline \multirow{5}{*}{$\begin{array}{l}\text { Total } \\
\text { number of } \\
\text { latex vessel } \\
\text { rings }\end{array}$} & 2 & 1.638 & 1.270 & 0.0138 & 0.0410 & 0.0548 & 1.14 & 1.52 & 2.66 \\
\hline & 4 & 1.332 & 0.893 & 0.0112 & 0.0288 & 0.0400 & 0.80 & 1.11 & 1.91 \\
\hline & 6 & 1.110 & 0.595 & 0.0093 & 0.0102 & 0.0285 & 0.53 & 0.79 & 1.32 \\
\hline & 8 & 0.928 & 0.318 & 0.0078 & 0.0103 & 0.0181 & 0.29 & 0.50 & 0.78 \\
\hline & 10 & 0.767 & - & 0.0065 & - & 0.0065 & - & 0.18 & 0.18 \\
\hline \multirow{5}{*}{$\begin{array}{l}\text { Latex } \\
\text { vessel } \\
\text { size }\end{array}$} & 2 & 1.638 & 1.270 & 0.1909 & 0.4239 & 0.6148 & 1.26 & 1.82 & 3.08 \\
\hline & 4 & 1.332 & 0.893 & 0.1552 & 0.2981 & 0.4533 & 0.88 & 1.34 & 2.22 \\
\hline & 6 & 1.110 & 0.595 & 0.1294 & 0.1986 & 0.3280 & 0.59 & 0.97 & 1.56 \\
\hline & 8 & 0.928 & 0.318 & 0.1082 & 0.1061 & 0.2143 & 0.31 & 0.64 & 0.95 \\
\hline & 10 & 0.767 & - & 0.0894 & - & 0.0894 & - & 0.27 & 0.27 \\
\hline
\end{tabular}

${ }^{1} \mathrm{~N}=$ number of progenies/individuals within progenies.

$K_{1}, K_{2}=$ selection differential in standard measure (after Becker, 1984).

${ }^{2}+{ }_{\mathrm{w}}=$ Total genetic gain $\left(G_{g}+G_{w}\right)$.

${ }^{3}$ Expressed as the girth of the progenies measured $20 \mathrm{~cm}$ from the ground.

Table 8 - Estimates of genotypic $\left(r_{g}\right)$ and phenotypic $\left(r_{p}\right)$ correlation coefficients based on individual plants among five in 20 open-pollinated rubber tree progenies.

\begin{tabular}{|c|c|c|c|c|}
\hline Traits & Growth vigor $^{1}$ & Bark thickness & $\begin{array}{l}\text { Total number of } \\
\text { latex vessel rings }\end{array}$ & Latex vessel size \\
\hline \multirow[t]{2}{*}{ Rubber yield } & $0.7330 * *$ & $0.7055^{* *}$ & $0.6387 * *$ & 0.2286 \\
\hline & $0.7072 * *$ & $0.7525^{* *}$ & $0.8025 * *$ & 0.2834 \\
\hline \multirow[t]{2}{*}{ Growth vigor } & & $0.7518^{* *}$ & 0.2461 & 0.4172 \\
\hline & & $0.8420 * *$ & 0.3010 & 0.6037 \\
\hline \multirow[t]{2}{*}{ Bark thickness } & & & $0.5490 *$ & $0.6656^{* *}$ \\
\hline & & & $0.6510 * *$ & $0.7890 * *$ \\
\hline \multirow{2}{*}{$\begin{array}{l}\text { Total number of latex } \\
\text { vessel rings }\end{array}$} & & & & 0.3050 \\
\hline & & & & $0.6047 * *$ \\
\hline
\end{tabular}

${ }^{*} \mathrm{p}<0.05, * * \mathrm{p}<0.01$

${ }^{1}$ Expressed as the girth of the progenies measured $20 \mathrm{~cm}$ from the ground. 
vigor and increased bark thickness correlated with yield to varying degrees. A positive genotypic and phenotypic association between the average yield and the number of latex vessel rings was not evident.

The lack of a significant genotypic and phenotypic correlation between growth vigor and the total number of latex vessel rings and between yield and latex vessel size indicated that there would be a low genetic gain for all of these traits, even if selection were undertaken for only one trait.

\section{Breeding strategy}

The results of this study provide a basis for developing a program to improve rubber tree selection. The "progeny plus within-progeny selection" method is currently the predominant form of selection used in most advanced tree improvement programs (Zobel and Talbert, 1984). This method consists of selecting the best progenies and the best individuals among these progenies. We intend to adopt this method to improve the yield of rubber, growth vigor and total number of latex vessel rings. Since there is significant genetic correlation among the three characters, direct selection can be used in this case. For this purpose, "massal selection" will be used, i.e., growth vigor will be selected first. When a desired level of growth vigor has been obtained, breeding efforts will be concentrated on yield. However, if a simultaneous improvement in yield and growth vigor were desired, then an independent culling method would be recommended.

\section{Acknowledgments}

The authors thank Ligia Regina Lima Gouvêa, Graziela dos Santos Lima and Andréa Cardoso Guerreiro of the Hevea breeding program at the Instituto Agronômico de Campinas (IAC) for their help during this study. P.S.G. and A.L.M.M. are recipients of CNPq fellowships. This work and its publication were supported by FAPESP.

\section{References}

Alika JE (1985) Heritability and genotypic gain from selection rubber (Hevea brasiliensis). Silvae Genet 34:1-4.

Alika JE and Onokpise OV (1982) Estimation of heritability parameter for yield, growth vigour and bark thickness in rubber (Hevea brasiliensis) from a single pair mating (S.P.M) design. J Plan Crops 10:102-108.

Becker WA (1984) Manual of Quantitative Genetics. Washington State University Press, Pullman, 195 pp.

Boock MV, Gonçalves PS, Bortoletto N and Martins ALM (1995) Herdabilidade, variabilidade genética e ganhos genéticos para produção e caracteres morfológicos em progênies jovens de seringueira. Pesq Agrop Bras 30:673-681.

Costa RB (1999) Métodos de seleção, interação genótipo x ambiente e ganho genético para o melhoramento da seringueira no Estado de São Paulo. PhD Thesis, Universidade Federal do Paraná, Curitiba, 185 pp.
Costa RB, Resende MDV, Araújo AJ, Gonçalves PS and Higa AR (2000a) Selection and genetic gain in rubber tree (Hevea) populations using a mixed mating. Genet Mol Biol 23:671679.

Costa RB, Resende MDV, Araujo AJ, Gonçalves OS and Bortoletto N (2000b) Seleção combinada univariada e multivariada aplicada ao melhoramento genético de seringueira Pesq Agrop Bras 35:381-388.

Falconer DS and Mackay TFC (1996) Introduction to Quantitative Genetics. New York, Longman, 320 pp.

Fisher RA and Yates F (1971) Statistical Methods for Research Workers. Oliver and Boyd, Edinburgh, 245 pp.

Gonçalves PS, Bortoletto N, Santos WR, Ortolani AA, Gottardi MVC and Martins ALM (1998) Avaliação genética de progênies em meios-irmãos de seringueira em diferentes regiões do Estado de São Paulo. Pesq Agrop Bras 33:10851095.

Gonçalves PS, Cardoso M, Colombo CA, Ortolani AA, Martins ALM and Santos ICI (1990) Variabilidade genética da produção anual de seringueira: estimativas de parâmetros genéticos e estudo da interação genótipo $\mathrm{x}$ ambiente. Bragantia 49:305-320.

Gonçalves PS, Furtado EL, Bataglia OCB, Ortolani AA, May A and Beletti GO (1999) Genetics of anthracnose panel canker disease resistance and its relationship with yield and growth character in half progenies of rubber tree (Hevea brasiliensis). Genet Mol Biol 22:583-589.

Gonçalves PS, Martins ALM, Bortoletto N and Carvalho AZ (1995) Relationship among yield girth and some structural characters of the laticiferous system in young seedling of rubber tree (Hevea). Braz J Genet 18:421-428.

Gonçalves PS, Martins ALM, Bortoletto N and Tanzini MR (1996) Estimates of genetics parameters and correlations of juvenile characters based on open pollinated progenies of Hevea. Braz J Genet 19:105-111.

Gonçalves PS, Martins ALM, Gorgulho EP, Bortoletto N, Cardoso M and Bermond G (1992) Variação genética dos componentes de crescimento em progênies jovens de uma população de clones de Hevea. Bragantia 51:161-171.

Kempthone O (1966). An Introduction to Genetic Statistics. John Wiley \& Sons, New York, 455 pp.

Lepsch LF and Valadares JMS (1976) Levantamento pedológico detalhado da Estação Experimental de Pindorama, SP. Bragantia 35:13-40.

Moreti D, Gonçalves PS, Gorgulho EP, Martins ALM and Bortoletto N (1994) Estimativas de parâmetros genéticos e ganhos esperados com a seleção de caracteres juvenis em progênies de seringueira. Pesq Agrop Bras 29:1099-1109.

Nga BH and Subramanian S (1974) Variation in Hevea brasiliensis, I. Yield and growth vigour data of the 1937 hand pollinated seedlings. J Rubber Res Inst Malays 24: 69-74.

Paiva JR, Gonçalves PS and Valois ACC (1983) Avaliação preliminar de comportamento de novos clones de seringueira em Manaus. Pesq Agrop Bras 18:147-158.

Paiva JR, Miranda Filho JB, Siqueira ER and Valois ACC (1982) Produção e ganho genético de alguns caracteres em seringueira em três esquemas de seleção. Pesq Agrop Bras 17:1646-1653. 
Siqueira GR (1978) Estimativas de parâmetros genéticos de seringueira (Hevea spp.) em condições de viveiro. MSc Thesis, Universidade Federal de Viçosa, Viçosa, 76 pp.

Tan H (1977) Estimates of general combining ability in Hevea breeding at the Rubber Research Institute of Malaysia. 1. Phase II and III a. Theor Appl Genet 50:29-34.

Tan H (1978a) Assessment of parental performance of yield in Hevea breeding. Euphytica 27:511-512.

Tan H (1978b) Estimates of parental combining abilities in rubber (Hevea brasiliensis) based on young seedlings progeny. Euphytica 27:817-823.

Tan H and Subramanian S (1976) A five-parent diallel cross analysis for certain characters of young Hevea seedlings. In: Proceedings of International Rubber Conference, 1975, RRIM, Kuala Lumpur, pp 13-16.
Tan H, Mukherjee TK and Subramniam S (1975) Estimates of genetic parameters of certain characters in Hevea brasiliensis. Theor Appl Genet 46:181-190.

Valois ACC, Pinheiro E, Conceição HEO and Silva MNC (1978) Competição de porta-enxertos de seringueira e estimativas de parâmetros genéticos. Pesq Agrop Bras 13:49-59.

Varghese YA (1999) Germoplasm resources and genetic improvement. In: Sethuraj MR and Mathew NM (eds) Natural Rubber: Biology, Cultivation and Technology. Elsevier Science Publishers, Amsterdam, pp 88-115.

Vencovsky R (1983) Herança quantitativa. In: Paterniani EC and Viegas GP (eds) Melhoramento e Produção do Milho. 2nd ed. Fundação Cargill, Campinas, pp 137-214.

Vencovsky R and Barriga P (1992) Genetica Biometrica no Fitomelhoramento. Sociedade Brasileira de Genética, Riberião Preto, 486 pp.

Zobel B and Talbert J (1984) Applied Forest Tree Improvement. John Wiley \& Sons, New York, 503 pp. 